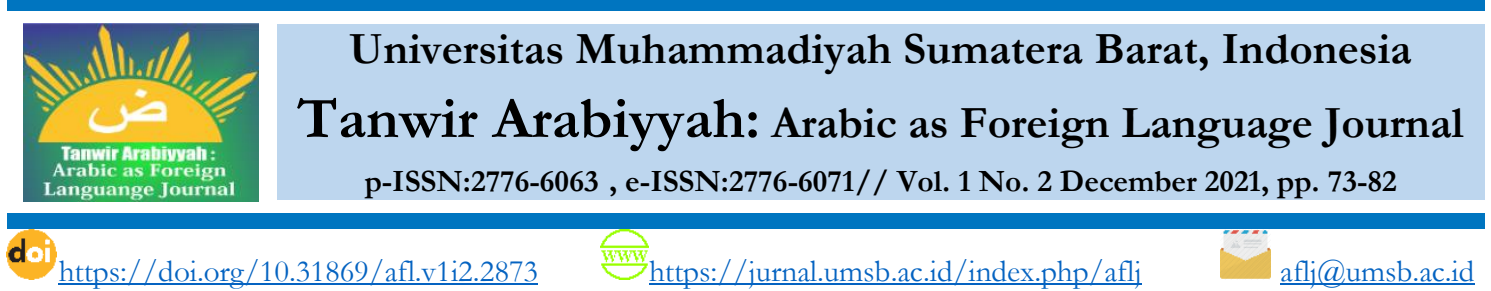

\title{
Fun Arabic Learning through Songs Media
}

\author{
*Umi Hanifah \\ Universitas Islam Negeri Sunan Ampel Surabaya, Indonesia \\ umihanifah@uinsby.ac.id
}

$\begin{array}{ll}\text { Article History: } & \text { In this study, the authors focused on learning Arabic through songs media. } \\ \text { Received: 17-09-2021 } & \text { The research method in this study is descriptive using a qualitative approach. } \\ \text { Revised: } 04-12-2021 & \text { Through studies from various sources in the form of books, journals, } \\ \text { Accepted: 10-12-2021 } & \text { research reports, and the phenomenon of Arabic learning in Indonesia, the } \\ \text { Published: 10-12-2021 } & \text { author describes how the concept of songs as a medium of Arabic learning } \\ \text { and how the implementation of songs media in Arabic learning as an effort to } \\ \text { improve the quality of Arabic learning. The conclusion of this study is that } \\ \text { the song is an appropriate medium of Arabic learning in arousing students' } \\ \text { interest and motivation to learn. The use of songs media in Arabic learning } \\ \text { can create an atmosphere of learning that is relaxed, fun and exciting, so } \\ \text { students do not feel bored and fed up in following the learning process in } \\ \text { class. The selection of songs that suits students' emotional and intellectual } \\ \text { needs and the teacher's skills in practicing the technique of using song media } \\ \text { in Arabic learning is the main key to the success of a learning that uses songs } \\ \text { as a instructional medium. } \\ \text { *Corresponding Author: } \\ \text { Instructional media; Song; Arabic learning; Fun learning } \\ \text { Keyword } \\ \text { Copyright C 2021, Umi Hanifah } \\ \text { This is an open access article under the CC-BY-SA license }\end{array}$

\section{INTRODUCTION}

Fun learning process is one of the factors supporting the success of a learning. Because when learning is done in a fun and interesting way, the material to be learned will be very easily accepted and understood well. For this reason a teacher is required to have creativity to use learning techniques and innovative learning media that can create a conducive and pleasant atmosphere so that in the end it gets the expected results (Mudofir, 2015).

Regarding Arabic learning, it is often assumed by most people that Arabic is very difficult to learn (Handriawan, 2015). Likewise, the assumption of students that Arabic subjects are boring subjects causes students to become students who are very clever to create a more interesting atmosphere so that students do not feel bored. Students will quickly get bored if they have difficulty understanding the contents of the material being taught and monotonous teaching methods such as too much lecture or verbalism (Wafi, 2019). 
One way to create a fun learning atmosphere, namely a learning atmosphere that is far from bored and scary, so students can focus their attention fully on learning (Umi Hanifah, 2016), then the teacher should present the material using media that can increase the enthusiasm and enthusiasm of learning from students. One of the media that is suitable in arousing students' interest in learning is the media "song". Through songs that are sung the learning atmosphere becomes more relaxed and pleasant so it does not make students become bored and bored in following the teaching and learning process in class (Hanifah, 2014).

The song is often also called the Song. Song or song is a poem that is pronounced according to the tone, rhythm, bar, and certain melody to form harmony. The song is often also referred to as a song which means the composition of tone or sound art in the sequence, combination, and temporal relationships (usually accompanied by musical instruments) to produce musical compositions that have unity and continuity (containing rhythm) (Setyadi et al., 2015). So singing is to recite poems according to the tone, rhythm, and certain melodies to form harmony. Singing is part of a variety of learning media, while singing is part of a variety of learning methods (Qomaruddin, 2017).

The fundamental reason for the use of song media for Arabic learning for students is to provide additional practice in vocabulary that they are familiar with through a fun medium that is song (Hanifah, 2018). Creative and resourceful teachers who know this situation can develop techniques to teach simple songs to improve students' vocabulary mastery each time they teach. Teachers and students can also create their own short songs (songs) containing vocabulary that students have learned that are taken from their textbooks (Nasir \& Huda, 2019).

The songs that are used may be very simple, but with the increasing development of their language, increasingly complicated songs can be presented even with the appropriate musical accompaniment. Then through singing, the teacher can convey a variety of learning material more easily and interestingly and the child can remember it longer because the song (singing) can be repeated and sung whenever and wherever (Inten et al., 2016).

Therefore, in this study the writer focuses on Arabic learning through song or song media. Through the study of various sources of literature, in this study the writer will explain how the concept of song as a medium of Arabic learning and how the implementation of song media in Arabic learning as an effort to improve the quality of Arabic learning.

\section{METHOD}

The research method in this study is descriptive using a qualitative approach, which is a study used to describe and analyze phenomena, events, social activities, attitudes, thoughts of individuals individually or in groups (Machmud, 2016).

Through the study of various sources of literature the author describes the use of song media in Arabic learning as an innovative and fun media that can be used by Arabic 
language teachers in animating the learning atmosphere. In answering the question of how the concept of songs as a medium for Arabic learning and how to implement media songs in learning Arabic, the author has examined various sources in the form of books, journals, research reports, and the phenomenon of Arabic learning in Indonesia. The results of the study are the authors of the series and compile in this scientific article with the Miles and Huberman data analysis methods, namely after the data is read, studied, and analyzed, then the data is reduced, presented, and drawn conclusions (Miles \& Huberman, 1994).

\section{RESULTS \& DISCUSSION}

\section{Definition of Song as Learning Media}

In Arabic, there are several terms used in learning media, including al-Wasail alIdhah atau al-Wasa'il al-Taudbihiyyah, (Ibrahim, 1968), al-Wasa'il al-Ta'lim, dan Al-Wasa'il al-Ta'limiyyah. Although the terms used are different, but all of them lead to the same understanding, namely learning media, which in history was first called visual aids (visual aids), then changed again to audio visual communication (communication of view of hearing), and finally to be educational technology (educational technology or learning technology) (Arsyad, 2003).

Whereas in Latin "media" is a plural form of "medium" which literally means "intermediary" or "introduction" that is the intermediary or introduction to the source of the message with the recipient of the message. AECT (Association of Education and Communication Technology) defines learning media as everything that can channel messages, can stimulate students' thoughts, feelings, and wishes so that they can encourage the creation of learning processes within students (Arsyad, 2003). Learning media is a channel tool to convey a message (message) or information from a source (resource) to the recipient (receiver). The message or information in learning is the teacher. While the recipient of the message or information is students. The combined message is in the form of a number of skills that students need to master.

Based on the above opinion it can be concluded that, learning media are all things that can be used as intermediaries / means to channel messages (learning materials), so as to stimulate the attention, interests, thoughts, and feelings of students in learning activities to achieve learning goals.

The learning process contains five components of communication. The five communication components in question are (1) teacher (communicator), (2) learning material, (3) learning media, (4) students (communicant), and (5) learning objectives.

Thus, the media is one of the five components of communication, namely as a messenger from the communicator to the communicant (Spector, 2015). This Related according by Hennig-Thurau et al., 2010, where he sees that the communication relationship will run smoothly with maximum results when using tools called communication media. Based on this definition, it can be said that the learning process is a communication process. 
As the author explained before, that the song is one of a variety of learning media. Songs are compositions of tone or sound in the order, combination, and temporal relationships that are usually accompanied by musical instruments to produce musical compositions that have unity and continuity that contains rhythm. The range of rhythmic notes or sounds is also called a son (Trainor \& Hannon, 2013).

Songs or rhythmic songs of music will enhance the content of memory of facts and details through rhymes, rhythm, and melody (Halimah, 2016). In learning Arabic, the material is packaged in songs or songs written by others, the teacher will increase the memory of students, especially if written by students themselves, it will be a great memory tool (Mufidah, 2019). It is stated that music is the science or art of arranging phrases or voices expressed, combinations and temporal relationships to produce sound compositions that have balance and unity, tones or sounds arranged in such a way that they contain rhythm, song and harmony especially those that can produce sounds those sounds.

Music and songs (songs) are elements of art or art that cannot be separated from one another. Even with the demonstration between music and song, it produces a beautiful art and can keep people's hearts entertained. Music and songs (songs) can be developed by one's talents through education and practice. Harmonious music is the best stimulus for brain development. When listening to music, song lyrics will stimulate the left brain and the melody will stimulate the right brain (Suwandari, 2014).

Learning Arabic is a fun activity for some people and troublesome for others. It's fun if done with an easy method, a fun teacher, and appropriate and interesting learning media, so learning Arabic is not boring. Conversely, learning Arabic becomes troublesome because it is done with complicated methods, monotonous and uncreative teachers, and inadequate learning media. So that it can cause frustration in students.

Learning media in the form of songs (songs), medically can be a therapy for people who are stressed, frustrated, and even depressed. That is because, when singing a song, the sound will vibrate the skull, so the brain seems to be massaged and releases the hormone serotonin which is a natural anti-depressant in the body. Therefore, after singing humans feel good, relieved and relaxed (Andani, 2017). Songs sung to musical accompaniment can affect pulse rate, blood pressure and breathing. For example a song whose tempo is rather Writing a song then singing it can avoid the boredom of students who are the main enemies in learning Arabic, this is caused by several factors including: (1) song (song) is liked by almost all students including shy students, so that all students can practice the pronunciation of simple expressions in Arabic, (2) songs (songs) are generally contextualized so that it is easy for students to memorize, thereby enriching their vocabulary (mufradat), (3) songs (songs) usually contain words, phrases or sentences that are repeated so that they will be easily remembered and reproduced by students, (4) songs (songs) will be happy to be sung by students outside the classroom, so long over time they will become familiar with Arabic, so that Arabic is no longer a foreign language for them, and (5) singing a song can make participants students are more happy and enjoy learning so 
that it helps them to more quickly understand the material and learning goals are easily achieved.

Writing a song then singing it can avoid the boredom of students who are the main enemies in learning Arabic, this is caused by several factors including: (1) song (song) is liked by almost all students including shy students, so that all students can practice the pronunciation of simple expressions in Arabic, (2) songs (songs) are generally contextualized so that it is easy for students to memorize, thereby enriching their vocabulary (mufradat), (3) songs (songs) usually contain words, phrases or sentences that are repeated so that they will be easily remembered and reproduced by students, (4) songs (songs) will be happy to be sung by students outside the classroom, so long over time they will become familiar with Arabic, so that Arabic is no longer a foreign language for them, and (5) singing a song can make participants students are more happy and enjoy learning so that it helps them to more quickly understand the material and learning goals are easily achieved.slow heart rate and breathing will adjust to the tempo of the music. Therefore, music and songs (songs) can also be referred to as a picture of human life to achieve an essential happiness and as long as it does not deviate from Islamic teachings or laws.

\section{The Purpose of Using Songs as a Medium for Arabic Learning.}

Writing a song then singing it can avoid the boredom of students who are the main enemies in Arabic learning, this is caused by several factors including: (1) song (song) is liked by almost all students including shy students, so that all students can practice the pronunciation of simple expressions in Arabic, (2) songs (songs) are generally contextualized so that it is easy for students to memorize, thereby enriching their vocabulary (mufradat), (3) songs (songs) usually contain words, phrases or sentences that are repeated so that they will be easily remembered and reproduced by students, (4) songs (songs) will be happy to be sung by students outside the classroom, so long over time they will become familiar with Arabic, so that Arabic is no longer a foreign language for them, and (5) singing a song can make participants students are more happy and enjoy learning so that it helps them to more quickly understand the material and learning goals are easily achieved (Nurhidayati \& Ridhwan, 2014).

Learning Arabic will feel more relaxed and fun if done by listening to the song / song / nasyid, because indirectly students will be motivated to know what the song is about.

In addition to several reasons for the use of songs (songs) as a medium of learning above, the main objectives of using songs (songs) as a medium in learning Arabic include: (1) to foster students' sensitivity to sound, rhythm, and tone in language Arab; (2) to train students in saying simple expressions in Arabic; (3) to train students in using Arabic vocabulary in songs; (4) to develop games with sounds in Arabic; (5) to develop a game with a memorized song demonstration; (6) to introduce spelling, news sentences, questions, and commands to students; (7) to make links between activities and objects / objects through song poetry; (8) to absorb the sounds of Arabic; (9) to develop students' sensitivity to rhythm; (10) to practice the concentration of students; (11) to eliminate teacher and student fatigue; and (12) to memorize vocabulary (Hanifah, 2018). 
Students at all levels of school will feel happy if invited to sing, play and repeat songs that are short in learning activities. Arabic teachers in schools or madrasas can take advantage of this natural tendency for learning Arabic in their classrooms. Songs, classical drills and playing with short songs can be used to create a pleasant atmosphere, arouse students' interest and enthusiasm for learning, besides being used as a medium for learning vocabulary (mufrodat), Arabic melodies and as a tool for correcting wrong speech without causing shame on the part of students who study.

In the use of songs as a medium for Arabic learning, there are two factors that determine the success of learning Arabic, namely: first, determine or choose a song that can answer the emotional needs of students and intellectually attractive students. Second, planning learning activities (RPP) that utilize songs with the aim to be able to meet several requirements such as: fun, can maintain and increase interest and motivation to learn, can be used as a tool to learn to recite new sounds, help learning new words and concepts through suitable actions and dramatization (Susanti et al., 2020).

\section{Criteria for Selecting Songs as a Medium for Arabic Learning}

One of the factors that determine the success of Arabic learning with song media is the determination or selection of songs that are appropriate to students' emotional and intellectual needs. Arabic teachers should always consider the type of song (song) that is appropriate for students. This is important so that students have the motivation, interests and positive feelings towards the Arabic language material being taught.

There are several criteria that can be used in selecting or determining the appropriate song in Arabic learning, including: (1) songs that are musical accompaniment or the rhythm does not dominate, because it can reduce students' understanding of the contents of the song. Because back-sounding music is too loud is a factor that can make it difficult for students to be able to understand the contents of a song. (2) the combination of music, rhythm and text should be harmonious and song text is more highlighted than music. Here music only functions as a song accompaniment. (3) the text of the song should be clear so that it is easy for students to join in singing. (4) The language used in the song is not too difficult. (5) The theme of the song must be in accordance with the world of students. (6) the song is sought to have a relationship with the material being taught (Hanifah, 2014).

In addition to the aforementioned factors, several factors concerning students themselves must be considered, namely: first, the level of mastery of the Arabic language they learn, the level of mubtadiin or mutaqaddimin; second, the age of students (children, adolescents or adults), as well as; third, students' interest in certain songs.

The use of song media in Arabic learning does not only involve listening, speaking and vocabulary aspects, but also the structure and aspects of culture. Through songs (songs), various aspects of a country's culture can be introduced. In learning Arabic, the use of songs (songs) with musical accompaniments allows students to achieve the ultimate goal of learning, namely the ability to understand Arabic both in terms of vocabulary and 
structure. Structural exercises using songs (singing) can train students' habit of using words or expressions in Arabic.

In learning Arabic through song media, the atmosphere of learning in the classroom is more relaxed and enjoyable, so as to reduce the tension and fear of students to talk and do exercises. Students are more motivated to learn, the material taught is also easily absorbed and memorized, because without realizing it they will continue to repeat it by singing it, both inside and outside the classroom. Furthermore, the song (song) will remain in their heads and they will sing it even though the lesson is over, they will hum it on the way home, and sing it repeatedly at home.

\section{The Technique of Using Songs in Arabic learning}

There are some techniques that teachers can use to use song media in Arabic learning:

The first technique, namely: giving incomplete song text to students, then playing the song from the text in full three times. After the incomplete song text has been filled in, the students are then asked to sing the song together. After that, students are asked to discuss the contents of the song, and finally the teacher gives questions to the students about the contents of the song they have heard and they sing together.

The second technique, namely: by giving song text clippings. Then the song cutouts are put into an envelope before the song is played. Furthermore, students open the envelope in which there are songs that are still irregular, and their task is to arrange the song poems in accordance with the sound of the song they hear. After the song is arranged correctly, students are asked to sing it together.

The third technique, students are asked to choose the desired song title. Then students hear the song from audio media or from the teacher directly. After that, students are asked to sing the song by following the rhythm and song lyrics on the audio media. Furthermore, students are asked to record the vocabulary of the song poetry that they listen to without looking at the song book to try their listening skills (mahma istma '). After that, students match the recorded writing with the song text that is displayed by the teacher or in the song book. Furthermore, students try to understand the meaning of the song while looking at the song text accompanied by audio media or the teacher's voice at normal speed. After that, students return to singing the song without seeing the song text or the accompaniment of music or the teacher's voice. So, the students invite their friends to join in singing the song together.

The basic principle that teachers must always remember in Arabic teaching and learning, songs is that the words in the song taught should not be shown before all the concepts in the song are understood and the rhythm of the song is introduced to students. Maybe some people doubt the ability of students in elementary schools to learn to sing an Arabic song without seeing the text, but in reality they can do it easily. Even a 3-year-old boy can sing a little star song or my balloon there are five Arabic versions without knowing how they are written. 


\section{Examples of songs in learning Arabic}

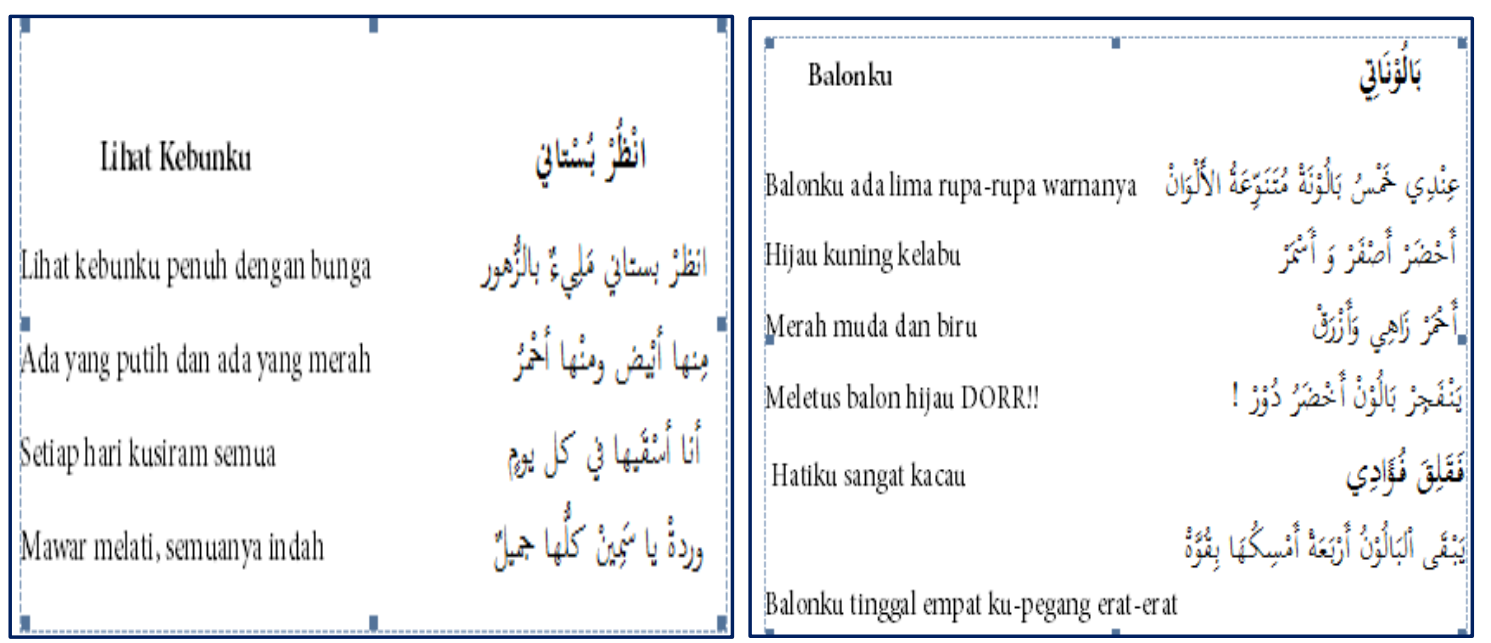

Songs that are suitable to be used as a medium for learning Arabic are songs whose lyrics are popular and the vocabulary easily imitated by students. Like Indonesian children's songs or national anthems that are popular and have been translated to the following Arabic:

\begin{tabular}{|c|c|}
\hline \multicolumn{2}{|l|}{ ans } \\
\hline Dua Mata Saya & 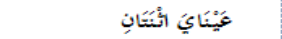 \\
\hline Dua mat a saya hidung saya satu & 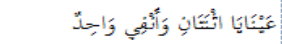 \\
\hline Dua kaki saya pakai sepatu baru & 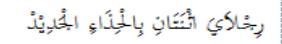 \\
\hline Dua tangan saya yang kiri dan kanan & 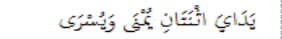 \\
\hline satu mulut saya membaca al-Qur'an & 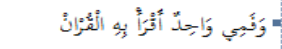 \\
\hline Dua mat a saya hidung saya satu & 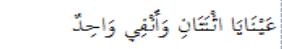 \\
\hline Dua kaki saya pakai sepatu baru & 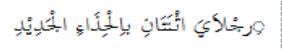 \\
\hline Dua tangan saya yang kiri dan kanan & 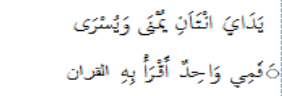 \\
\hline Satu mulut saya membaca al-Qur'an & \\
\hline
\end{tabular}

\begin{tabular}{|c|c|}
\hline Kring Suara Sepech & 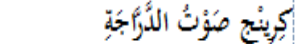 \\
\hline Kring kring kring bunyi sepeda & 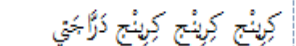 \\
\hline Sepedaku roda tiga & 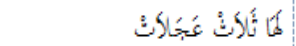 \\
\hline Kudapat dari ayah karena rajin belaja & 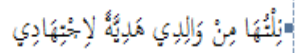 \\
\hline Tok tok tok suara sepatu & 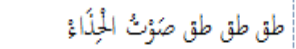 \\
\hline Sepatuku kulit lembu & 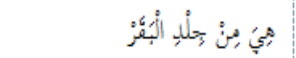 \\
\hline Kudapat dari ibu & 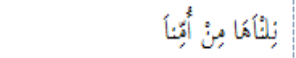 \\
\hline Karena rajin membantu $3 \mathrm{X}$ & 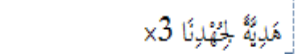 \\
\hline
\end{tabular}

\begin{tabular}{|c|c|}
\hline Indonesia Pusaka & 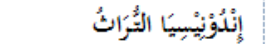 \\
\hline Indonesia tanah air beta & 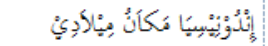 \\
\hline Pusaka abadi nan-jaya & 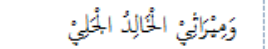 \\
\hline Indonesia sejak dulu kala & 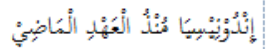 \\
\hline Tetap di-puja-puja bangsa & 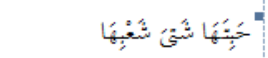 \\
\hline Di sana tempat lahir beta & 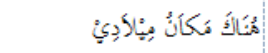 \\
\hline Dibuai dibesarkan bunda & 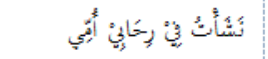 \\
\hline Tempat berlindung di hari tua & 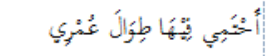 \\
\hline Sampai akhir menutup mata & 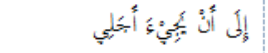 \\
\hline
\end{tabular}




\section{CONCLUSIONS}

Based on the results of the study of various references and phenomena that exist, it can be concluded that the song is one of the Arabic learning media that is appropriate in arousing students' interest and motivation to learn. The use of song media in learning Arabic can create a learning atmosphere that is relaxed, fun and exciting, so students do not feel bored and fed up in following the learning process in class. The selection of songs that suits students' emotional and intellectual needs is the main key to the success of a learning process that uses songs as a learning medium. In addition, teachers must be skilled in practicing the technique of using song media in learning Arabic.

For Arabic teachers who rarely use songs in their learning, especially because the teachers themselves don't like to sing, the teacher has actually missed something very special. Because most students like to sing, even the song will remain in their heads and they will sing it even though the lesson is over. For this reason, Arabic teachers can use songs (songs) as alternative, innovative and fun learning media in learning Arabic.

\section{BIBILIOGRAPHY}

Andani, C. (2017). Kecemasan Sosial Anak Tunadaksa Ditinjau dari Penerapan Terapi Lagu Anak di YPAC Semarang dan SLB N Ungaran. In UNNES. Universitas Negeri Semarang.

Arsyad, A. (2003). Media Pembelajaran. Raja Grafindo Persada.

Halimah, L. (2016). Musik dalam Pembelajaran. EduHumaniora: Jurnal Pendidikan Dasar, 2(2), 1-9. https://ejournal.upi.edu/index.php/eduhumaniora/article/view/2763/1803

Handriawan, D. (2015). Mempertegas Kembali Arah Pembelajaran Bahasa Arab. Al Mahāa: Jurnal Pendidikan Bahasa Arab, 1(1), 43-64. https:/ / doi.org/10.14421/almahara.2015.011-03

Hanifah, U. (2014). Media Pembelajaran Bahasa Arab (Vol. 1). UIN Sunan Ampel.

Hanifah, U. (2018). Pengembangan Literasi Berbicara Bahasa Arab (Maharat Al-Kalam) di Madrasah Ibtidaiyah (MI). Elementary: Islamic Teacher Joumal, 6(2), 206-226. https://doi.org/http://dx.doi.org/10.21043/elementary.v6i2.4383

Hennig-Thurau, T., Malthouse, E. C., Friege, C., Gensler, S., Lobschat, L., Rangaswamy, A., \& Skiera, B. (2010). The impact of new media on customer relationships. Journal of Service Research, 13(3), 311-330. https://doi.org/10.1177/1094670510375460

Ibrahim, A. (1968). al-Muwaijah al-Fanny Li Mudarris al-Lughah al-'Arabiyyah (4th ed.). Dar alMa'arif. 1522508987Gg3P9.pdf

https://books-library.net/files/download-pdf-ebooks.org-

Inten, D. N., Permatasari, A. N., \& Mulyani, D. (2016). Literasi Dini Melalui Teknik Bernyanyi. AL MURABBI, 3(1), 70-91.

Machmud, M. (2016). Tuntunan Penulisan TUGAS AKHIR Berdasarkan Prinsip Dasar Penelitian Ilmiah. In Penerbit Selaras. Penerbit Selaars. http://researchreport.umm.ac.id/index.php/research-report/article/view/872/1081 
Miles, M. B., \& Huberman, A. M. (1994). Qualitative Data Analysis. In Sage Publication (2nd ed.). Sage Publication.

Mudofir, I. (2015). Pembelajaran Inovatif untuk Meningkatkan Pembelajaran Bahasa Inggris yang Efektif. JLT Politeknik Negeri Malang, 5(1), 68-81.

Mufidah, N. (2019). Fun Arabic Teaching With Song Media for Primary Schools/Pengajaran Bahasa Arab Menyenangkan Dengan Media Lagu Untuk Madrasah Ibtidaiyah. Journal AL-MUDARRIS, 2(2), 166-185. https://doi.org/10.32478/al-mudarris.v2i2.277

Nasir, A., \& Huda, M. (2019). Mengarang Syair-Syair Arab Melalui Kebiasaan Menulis Siswa Dalam Kajian Arudh Wal Qowafi. Arabia: Jurnal Pendidikan Bahasa Arab, 11(2), 79-96. https:// doi.org/10.21043/arabia.v11i2.4862

Nurhidayati, N., \& Ridhwan, N. A. (2014). Strategi Pembelajaran Bahasa Arab untuk Anak (Issue March). Universitas Negeri Malang.

Qomaruddin, A. (2017). Implementasi Metode Bernyanyi dalam Pembelajaran Mufradāt. Jurnal Kependidikan, 5(1), 25-36. https://doi.org/10.24090/jk.v5i1.1240

Setyadi, A., Sudaryanto, E., \& Novaria, R. (2015). Analisis Semiotika Lagu-Lagu Suporter Persebaya Bonek Mania. Representamen, 1(02). http://jurnal.untagsby.ac.id/index.php/representamen/article/view/1451

Spector, J. M. (2015). The SAGE Encyclopedia of Educational Technology. The SAGE Encyclopedia of Educational Technology, May. https://doi.org/10.4135/9781483346397

Susanti, E., Ritonga, M., \& Bambang, B. (2020). Pengaruh Penggunaan Media Powerpoint Terhadap Minat Belajar Bahasa Arab Siswa. Arabiyatuna: Jurnal Bahasa Arab, 4(1), 179-191. https://doi.org/10.29240/jba.v4i1.1406

Suwandari, S. L. H. S. (2014). Penerapan Model Quantum Teaching Untuk Meningkatkan Hasil Belajar IPA Pada Siswa Kelas VI SDN Sidotopo III / 50 Surabaya. Jpgsd, 02(02), 1-11. https://media.neliti.com/media/publications/252590-none$226 \mathrm{~d} 7 \mathrm{c} 07 . \mathrm{pdf}$

Trainor, L. J., \& Hannon, E. E. (2013). Musical Development. In The Psychology of Music (Issue December). Department of Psychology, University. https://doi.org/10.1016/B978-0-12-381460-9.00011-0

Umi Hanifah. (2016). Penerapan Model PAIKEM dengan Menggunakan Media Permainan Bahasa dalam Pembelajaran Bahasa Arab. Ilmu Tarbiyah "At-Tajdid," 5(2), 301-330.

Wafi, A. (2019). Using Games to Improve Students' Active Involvement in the Learning of English Syntax at IAIN Madura: An Autonomous Learning. OKARA: Jurnal Bahasa Dan Sastra, 13(1), 107-120. https://doi.org/10.19105/ojbs.v13i1.2256 